\title{
Integrated Strip Foundation Systems for Small Residential Buildings
}

\author{
Torben Valdbjørn Rasmussen*
}

Department of Construction and Health, Danish Building Research Institute, Aalborg University, Denmark

\begin{abstract}
A prefabricated lightweight element was designed for a strip foundation that was used on site as the bases of two small residential buildings, in this case single-family houses; one was built with a double-brick exterior wall separated by mineral fiber insulation and the other was built with a wood-stud exterior wall with mineral fiber insulation. The element was placed on a stable surface underneath the top soil layer, just $0.25 \mathrm{~m}$ below the finished ground surface. The prefabricated element was designed to comply with the requirements of a high energy-efficient performance stipulated in the new Danish Building Regulations. The base of the two individual buildings was cast in one working operation and completed within two working days. Produced and shaped as one coherent element of expanded polystyrene, the element was designed to be handled on site by one man. Non-freezing ground was established by using outer insulation located at the outer plinth. Temperatures were measured at measurement points at the outer plinth and onwards from these points beneath the building. In addition the soil temperature, the temperature within the concrete floor slab and outdoor as well as indoor temperatures were measured.
\end{abstract}

Keywords: Strip foundation, Prefabricated element, EPS, Small building, Case study.

\section{INTRODUCTION}

In 2005 the Danish Government presented an action plan for the energy field. This action plan will have an impact on Danish energy-saving initiatives in the years to come [1]. The action plan includes a description of the Danish energy sector in the years leading up to 2025. One subject of the strategy is the climate policy related to the Kyoto Protocol [2], which entered into force on 16 February 2005. Signatory industrialized countries to the Protocol are obliged to limit their emissions of greenhouse gases between 2008 and 2012. As part of the internal distribution of obligations within the EU, Denmark must reduce its emissions by $21 \%$ before 2012 compared with 1990 emissions [3, 4]. Furthermore the draft action plan contains energy saving initiatives that are intended to reduce domestic energy consumption by an average of 1\% per annum from 2006 to 2012. In addition, the action plan also signals that long-term efforts must be made to keep energy consumption at current levels in the run-up to 2025.

The draft plan in particular focuses on energy consumption in buildings, where the largest and most cost-effective potential for energy savings lies. The new and most important initiatives are tightened energy provisions, introduced in 2006, in the Danish Building Regulations [5, 6], an improved energy-labeling scheme [6], enhanced supervision of boilers and ventilation installation systems, and finally a number of energy-saving initiatives within the public sector.

The tightened energy provisions in the Building Regulations will apply both to new and existing buildings. Besides

*Address correspondence to this author at the Department of Construction and Health, Danish Building Research Institute, Aalborg University, Denmark; Tel: +45 9940 2272; Fax: +45 4586 7535; E-mail: tvr@ sbi.dk the strengthening of current regulations from 2006, the plan paves the way for a further strengthening in 2010, 2015 and in 2020. The tightened energy provisions in the building regulations of 2006 will result in an energy reduction of $25 \%$ for new buildings compared with the former Building Regulations. The new Building Regulations have had an impact on energy consumption in buildings, in that the regulations focus on the thermal envelope as well as the individual building components. One focus area has been heat loss through the strip foundation of a building. In order to meet the new requirements for energy consumption, alternative solutions were needed to replace the strip foundation of concrete traditionally used in Denmark. These traditional foundations are typically of concrete and other cement-based materials and built $0.9 \mathrm{~m}$ below the finished ground surface in order to reach non-freezing ground with adequate bearing capacity.

Therefore, a new prefabricated lightweight element was designed and tested on site. The prefabricated element was used as strip foundation placed on the stable ground underneath the top soil layer, just $0.25 \mathrm{~m}$ below the finished ground surface. The prefabricated element was introduced as an alternative to the traditionally used solution and was designed to meet the same performance requirements as traditional solutions. However, when using the prefabricated element, there was no need to dig to a depth of $0.9 \mathrm{~m}$ below the finished ground surface and the base of the building was cast in one working operation. The base of the building was completed within two working days. The prefabricated element was produced and shaped as one coherent element of expanded polystyrene. The prefabricated element was designed to be handled on site by one man and to be used as the strip foundation of a building not exceeding two storeys. The expanded polystyrene element was specially designed to form the strip foundation that together with the ground floor slab represented the base of a small building with an exterior 
wall constructed as a traditional double-brick wall, a traditional wood-stud wall, or combinations of lightweight concrete, brick and wood-stud walls with insulation. Furthermore, the prefabricated element was designed to comply with the new Danish Building Regulations [7], by minimizing the heat loss through the strip foundation between the ground floor slab and the exterior wall. The expanded polystyrene element was specially designed to form a strip foundation that could be integrated into the insulation material located beneath the concrete floor slab. By applying a principle that contributes to a full and continuous insulation cover against the heated part of the building, integrating the insulation material beneath the concrete floor slab through the strip foundation to the insulation material in the exterior wall, the energy consumption in buildings can be reduced. The new prefabricated lightweight element used as the strip foundation contributed to a full and continuous insulation cover against the heated part of the building, allowing very little energy to be lost through the joint between the concrete floor slab and the exterior wall.

In the design phase, the design criteria were outlined, the methods for establishing stable non-freezing ground underneath the building were described and instructions were drafted on how to handle the prefabricated element on site. To enhance knowledge of the temperatures underneath the building, temperature measurement points were positioned along lines stretching from beneath the strip foundation at the outer plinth and onwards from these points beneath the building. In addition the soil temperature, the temperature within the concrete floor slab and the outdoor as well as the indoor temperatures were measured. Temperature measurements were compared with temperatures calculated from using a PC finite difference program.

\section{METERS FOR TEMPERATURE MEASUREMENTS}

\section{Embedded Temperature}

The temperature was measured with a type $\mathrm{T}$ thermocouples and a data logger, both type 605 and DT80 were used. The junction of the thermocouples was covered with epoxy. Data from the data logger were transferred to a PC and a computer program processed the results. The data logger was placed outdoors in a waterproof plastic container positioned over and above the finished ground surface. The plastic container was sealed to ensure a dry clean location for the data logger. The plastic container held an electrical supply for the data logger as well as a $10 \mathrm{~W}$ heating element. Measurement points were placed on site beneath the strip foundation, at the outer plinth and beneath the insulation layer in the ground floor slab as well as cast in the concrete floor slab of the building. In addition one measurement point was placed in the soil, approximately $0.4 \mathrm{~m}$ below the finished ground surface. Measurement points were not exposed to direct sunlight and were placed well away from any heat-producing appliances. The temperature was recorded every two hours.

\section{Air Temperature}

The indoor and the outdoor temperatures were measured by means of small data loggers. Data from the data loggers were transferred to a PC and a computer program processed the results. The data loggers were positioned at approximately 2 to $3 \mathrm{~m}$ above the finished ground surface, not ex- posed to direct sunlight and placed away from any heat or moisture producing appliances. The temperature was recorded every hour.

\section{STRIP FOUNDATION ELEMENT}

The prefabricated elements were made of expanded polystyrene that could be used as strip foundation of a small building not exceeding two storeys. Elements were produced and shaped as one coherent element in a production process that included an injection molding procedure. Expanded polystyrene is produced from a mixture of about $5-10 \%$ gaseous blowing agent (most commonly pentane or carbon dioxide) and $90-95 \%$ polystyrene by weight. The solid plastic is expanded into foam by means of heat, usually steam. The polystyrene is filled with trapped air, which gives it low thermal conductivity. This makes it ideal as a construction material used for insulation in building systems. In the following the expanded polystyrene will be referred to as EPS. The chemical structure of polystyrene is a long-chain hydrocarbon with every other carbon connected to a phenyl group (similar to benzene). The EPS has a glass temperature of 95 ${ }^{\circ} \mathrm{C}$ and a melting point of $240{ }^{\circ} \mathrm{C}$. The thermal conductivity of EPS is $0.034 \mathrm{~W} / \mathrm{mK}$. The prefabricated element consisted of units measuring $1.2 \mathrm{~m}$ in length and $0.6 \mathrm{~m}$ in width, (see Fig. 1). The prefabricated element is approximately $98 \%$ air by volume and has a density of $33.0 \mathrm{~kg} / \mathrm{m}^{3}$. The EPS has a characteristic short-term compressive strength equal to 250.0 $\mathrm{kPa}$ and long-term compressive strength equal to $75.0 \mathrm{kPa}$ with a $2 \%$ strain.

\section{PERFORMANCE-BASED CRITERIA FOR THE DE- SIGN OF STRIP-FOUNDATION ELEMENTS}

The prefabricated EPS element was designed to comply with the new revised Danish Building Regulations [5-7] which allow very little energy to be lost through the strip foundation between the ground floor slab and the exterior wall. In the following, heat loss through the strip foundation will be referred to as the surplus heat loss, $[\mathrm{W} / \mathrm{mK}]$. The surplus heat loss is defined as the heat flow that can be attributed neither to the heat flow through the ground floor slab nor to the exterior wall. Surplus heat loss through the joint between the ground floor slab and the exterior wall is closely related to the design of the strip foundation. The surplus heat loss is in the following calculated according to DS418 [8] Anneks D that is not equivalent to the principals used in the European standard ISO/DIS 13370 [9] determining the line losses for foundations.

To comply with the new energy provisions, incorporated in the Danish Building Regulations [7], the strip foundation of a building must in practice normally not exceed a surplus heat loss of $0.12 \mathrm{~W} / \mathrm{mK}$, when using heating in the concrete floor slab. The surplus heat loss must not exceed $0.15 \mathrm{~W} / \mathrm{mK}$ when using conventional heating in the building. The Danish Building Regulations require that, in practice, the overall coefficient of heat transmission of the ground floor slab and the exterior wall should be equal to or less than $0.12 \mathrm{~W} / \mathrm{m}^{2} \mathrm{~K}$ and $0.2 \mathrm{~W} / \mathrm{m}^{2} \mathrm{~K}$ respectively.

Calculations of the surplus heat loss through the prefabricated element were carried out by using a PC and the finite difference program HEAT2 version 5.0 [10] in accordance with the method described in Danish Standards [8]. Calcula- 


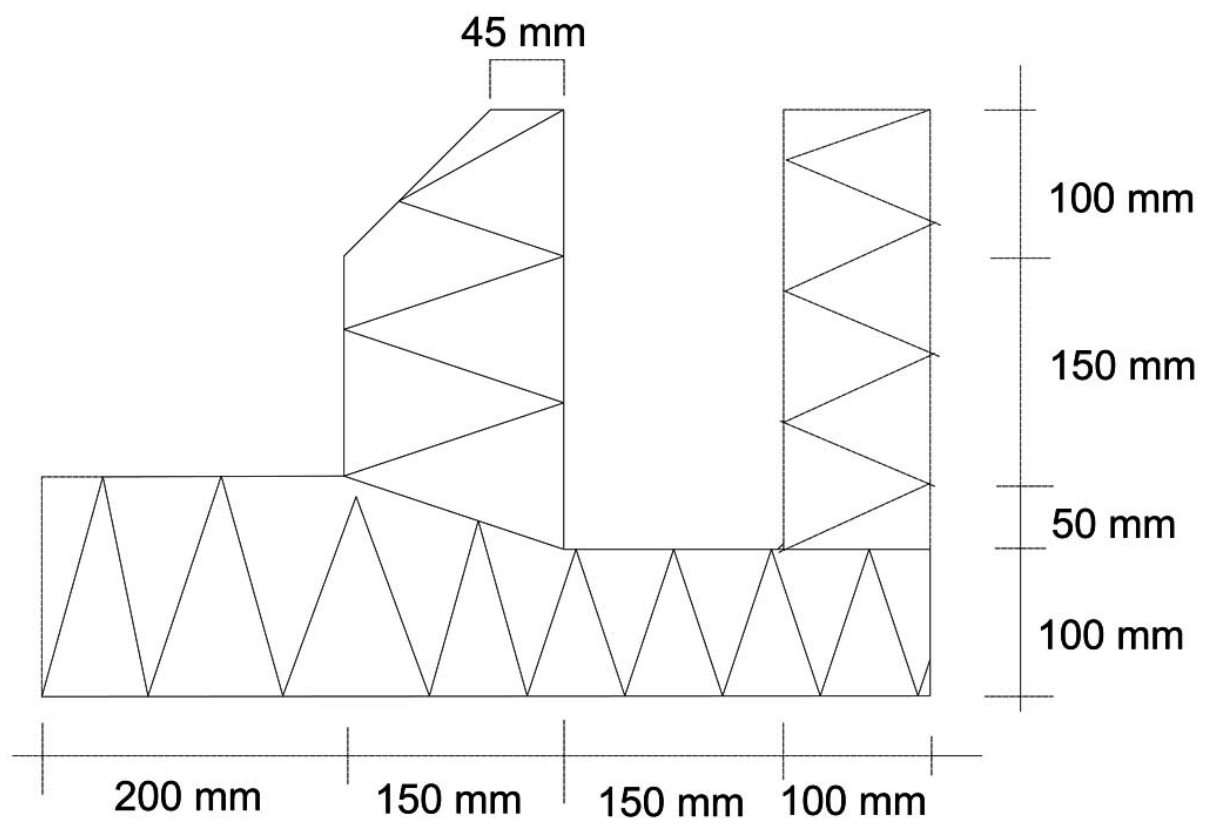

Fig. (1). The prefabricated EPS element.

tions are dynamic with the outdoor temperatures changing throughout the year, (see Fig. 4), outdoor temperature for a normal year. For the calculations the specific heat capacity of the soil and the thermal conductivity of the soil were set to $2.0 \mathrm{MJ} / \mathrm{m}^{3} \mathrm{~K}$ and $2.0 \mathrm{~W} / \mathrm{mK}$, respectively. Calculations are continued for a number of years, typically 3 years, until the heat flow through the surface at the interior side in December varies less than $1 \%$ from the calculation for December the former year. The surface at the interior side covers the floor surface and the interior surface of the exterior wall.

\section{Strip Foundation Supporting a Double-brick Wall}

Fig. (2) shows the prefabricated EPS element used as the strip foundation and the base of a building with a doublebrick exterior wall separated by mineral fiber insulation. The thermal conductivity of the materials of the exterior wall is

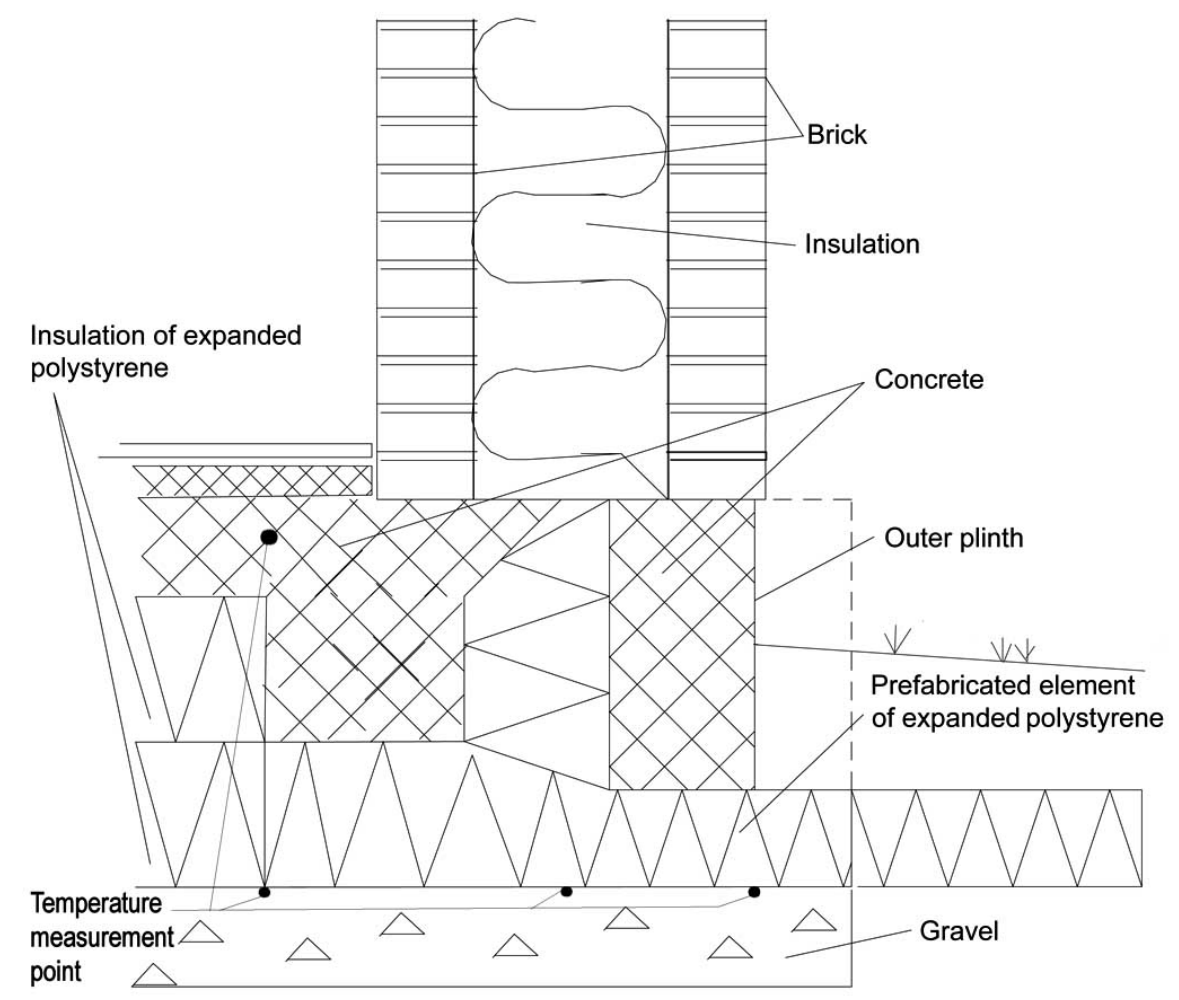

Fig. (2). The prefabricated EPS element used as the strip foundation of a double-brick exterior wall separated by mineral fiber insulation. 
$0.78 \mathrm{~W} / \mathrm{mK}, 0.037 \mathrm{~W} / \mathrm{mK}, 0.68 \mathrm{~W} / \mathrm{mK}$ for the exterior brick wall, mineral fiber insulation and interior brick wall. The thermal conductivity of the materials of the ground floor slab is $2.2 \mathrm{~W} / \mathrm{mK}, 0.034 \mathrm{~W} / \mathrm{mK}, 0.80 \mathrm{~W} / \mathrm{mK}$ for the reinforced concrete floor slab, EPS insulation and the stamped gravel layer, respectively. The thermal conductivity of concrete, without shrinkage crack reinforcement, is $1.6 \mathrm{~W} / \mathrm{mK}$. Stainless steel rods $5 \mathrm{~mm}$ in diameter were put through the EPS, every $0.6 \mathrm{~m}$, thus forming the mechanical fastening point of the concrete for the outer plinth and the concrete floor slab. The contribution of the mechanical fastening to the surplus heat loss through the strip-foundation element is 0.002 $\mathrm{W} / \mathrm{mK}$ [11, Table A.3.1].

The following calculations were made for a building with heating in the concrete floor slab. The exterior wall was designed to meet the limit on the overall coefficient of heat transmission equal to $0.2 \mathrm{~W} / \mathrm{m}^{2} \mathrm{~K}$. The surplus heat loss was calculated to be $0.14(0.135) \mathrm{W} / \mathrm{mK}$. When the warm side of the exterior brick wall was replaced by a lightweight concrete wall with a thermal conductivity of $0.45 \mathrm{~W} / \mathrm{mK}$; in the calculations, the surplus heat loss was calculated to be 0.14 (0.136) $\mathrm{W} / \mathrm{mK}$. When a calculation was made to assess the effect of increasing the thickness of the insulation within the exterior wall so that the overall coefficient of heat transmission of the exterior wall was equal to $0.18 \mathrm{~W} / \mathrm{m}^{2} \mathrm{~K}$, the surplus heat loss was calculated to be $0.14(0.137) \mathrm{W} / \mathrm{mK}$. Cal- culations were carried out with a temperature of the concrete floor slab of $30{ }^{\circ} \mathrm{C}$ and with an interim insulation to the soil of $1.5 \mathrm{~m}^{2} \mathrm{~K} / \mathrm{W}$ which allowed the overall coefficient of heat transmission of the ground floor slab to be $0.1 \mathrm{~W} / \mathrm{m}^{2} \mathrm{~K}$.

Using conventional heating in the building with the overall coefficient of heat transmission of the exterior wall equal to $0.2 \mathrm{~W} / \mathrm{m}^{2} \mathrm{~K}$, the surplus heat loss was calculated to be 0.13 (0.126) $\mathrm{W} / \mathrm{mK}$. When the brick wall was replaced, at the warm side of the exterior wall, with a lightweight concrete wall with the thermal conductivity $0.45 \mathrm{~W} / \mathrm{mK}$ the surplus heat loss was calculated to be $0.13(0.125) \mathrm{W} / \mathrm{mK}$. For an exterior wall that was less energy consuming, with an overall coefficient of heat transmission equal to $0.18 \mathrm{~W} / \mathrm{m}^{2} \mathrm{~K}$, the surplus heat loss was calculated to be $0.13(0.128) \mathrm{W} / \mathrm{mK}$. For the calculations the temperature towards the concrete floor slab was $20{ }^{\circ} \mathrm{C}$ with an interim insulation to the ground floor slab and soil of $1.67 \mathrm{~m}^{2} \mathrm{~K} / \mathrm{W}$, which allow the overall coefficient of heat transmission of the ground floor slab to be $0.09 \mathrm{~W} / \mathrm{m}^{2} \mathrm{~K}$.

\section{Strip Foundation Supporting a Wood-stud Wall}

Fig. (3) shows the prefabricated EPS element used as the strip foundation and the base of a building with a wood-stud exterior wall with mineral fiber insulation. When supporting a wood-stud exterior wall, the insulation underneath the concrete floor slab can have the same thickness throughout the

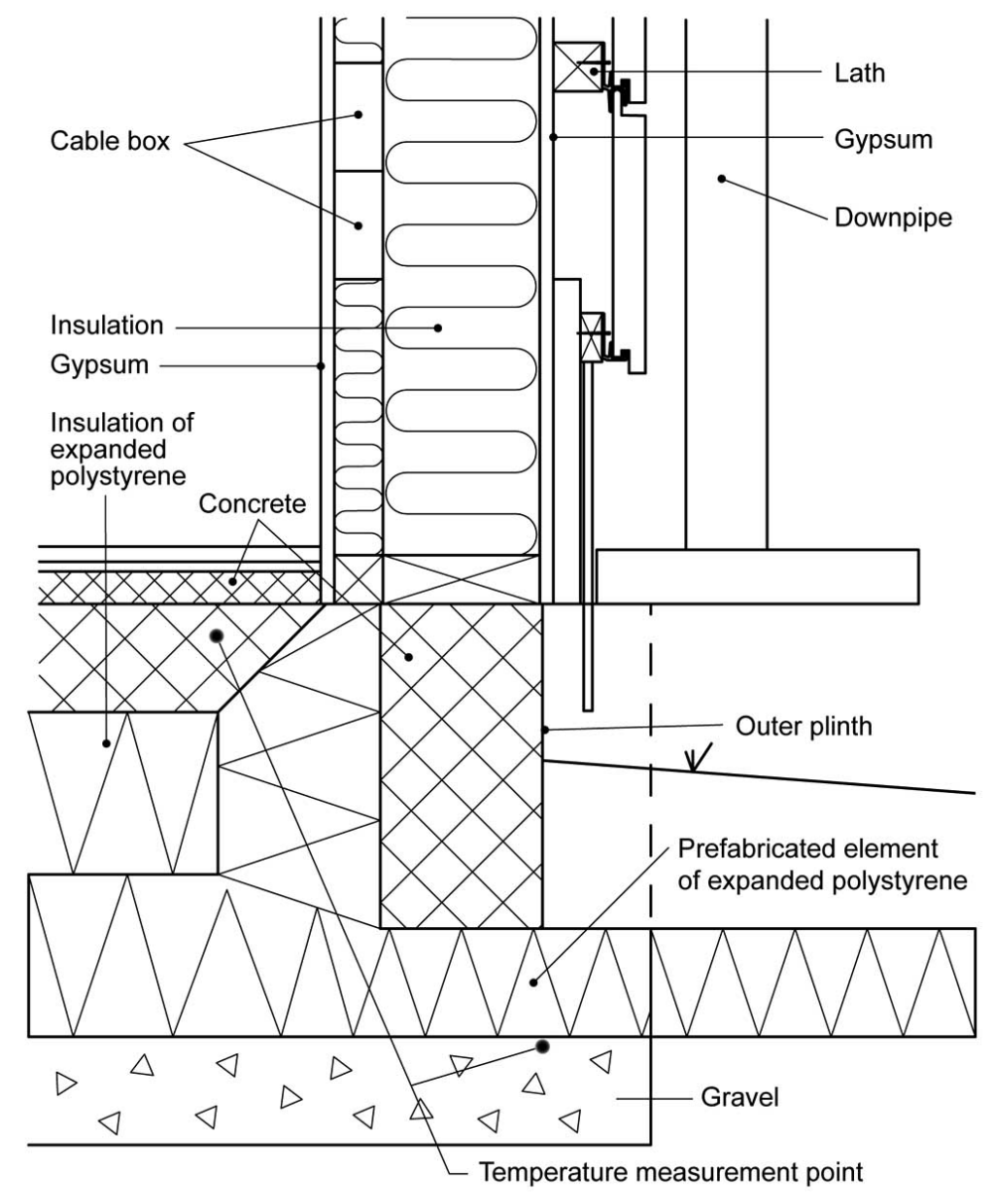

Fig. (3). The EPS element used as the strip foundation of a traditional wood-stud exterior wall with mineral fiber insulation. 
concrete floor slab. Hence the concrete beam needed for supporting the inner wall of the exterior wall is not necessary for a wood-stud wall. The exterior wood-stud wall is supported by the concrete beam behind the outer plinth. As for the prefabricated element to be used as the base of a traditional double-brick wall, stainless steel rods $5 \mathrm{~mm}$ in diameter were put through the EPS at every $0.6 \mathrm{~m}$ forming the mechanical fastening points of the concrete for the outer plinth and the concrete floor slab. The contribution of the mechanical fastening to the surplus heat loss through the stripfoundation element is $0.002 \mathrm{~W} / \mathrm{mK}$ [11, Table A.3.1]. For the design of the exterior wall to comply with the limit on the overall coefficient of heat transmission to be equal to 0.2 $\mathrm{W} / \mathrm{m}^{2} \mathrm{~K}$ of a building using heating in the concrete floor slab, the surplus heat loss was calculated to be 0.09 (0.091) $\mathrm{W} / \mathrm{mK}$. When a calculation was made to assess the effect of increasing the thickness of the insulation within the exterior wall so that the overall coefficient of heat transmission of the exterior wall was equal to $0.18 \mathrm{~W} / \mathrm{m}^{2} \mathrm{~K}$, the surplus heat loss was calculated to be $0.09(0.089) \mathrm{W} / \mathrm{mK}$.

For a design of the exterior wall to meet the limit on the overall coefficient of heat transmission equal to $0.2 \mathrm{~W} / \mathrm{m}^{2} \mathrm{~K}$ using conventional heating in the building, the surplus heat loss was calculated to be $0.09(0.094) \mathrm{W} / \mathrm{mK}$. For an exterior wall that was less energy consuming, with an overall coefficient of heat transmission equal to $0.18 \mathrm{~W} / \mathrm{m}^{2} \mathrm{~K}$, the surplus heat loss was calculated to be $0.09(0.092) \mathrm{W} / \mathrm{mK}$.

\section{ENSURING STABLE NON-FREEZING GROUND BE- NEATH THE EPS ELEMENT}

Ensuring stable non-freezing ground beneath the building is necessary in order to maintain the stability of the structure and to avoid settling cracks. To ensure stability of the strip foundation, it is important that temperatures below $-1{ }^{\circ} \mathrm{C}$ do not occur in any layer beneath the building susceptible to frost during a cold winter [12]. Temperatures below $-1{ }^{\circ} \mathrm{C}$ beneath the capillary breaking layer during a cold winter could cause frost deformations of the soil beneath, and this would increase the risk of settling of the strip foundation. EPS boards from the outer plinth of the strip foundation were used to form the part of the prefabricated element called the outer insulation. Due to the inertia of the soil in the ground, stable non-freezing ground underneath the building was es- tablished by outer insulation avoiding frost to penetrate to deep below the foundation. At the vicinity of a corner of the building, the necessary outer insulation was designed on the basis of the experience gained from using the PC finite difference program HEAT2 for 2D and HEAT3 for 3D calculations. Calculations showed that if the temperature was determined to be $+1.6^{\circ} \mathrm{C}$ along the facade of the building, this was equal to $-1{ }^{\circ} \mathrm{C}$ at the vicinity of a corner of the building. Experience was gained from calculations on different types of foundation, all at equal depths. Temperature characteristics for a cold winter were fed into the model using a design value of 100 years, based on the descriptions given in the Danish Standards [12], (see Fig. 4). Fig. (4) shows the outdoor temperatures for a cold winter. The lowest average temperature of a month was decreased from $-0.5{ }^{\circ} \mathrm{C}$ in a normal year to $-7.3{ }^{\circ} \mathrm{C}$ in a cold year [13].

Outer insulation was designed for three different cases describing the indoor temperatures, i) an indoor temperature of $20^{\circ} \mathrm{C}$, ii) an indoor temperature equivalent to the outdoor temperature but not lower than $5{ }^{\circ} \mathrm{C}$, and iii) an indoor temperature equivalent to the outdoor temperature.

Calculations showed that along the facade of a building, an outer EPS insulation, $0.1 \mathrm{~m}$ thick and extending $0.4 \mathrm{~m}$ in front of the outer plinth of a building facade only $0.15 \mathrm{~m}$ under the finished ground surface, was sufficient to keep the soil immediately beneath the gravel layer from freezing during a cold winter, while keeping an indoor temperature equivalent to the outdoor temperature.

At the vicinity of a corner where the prefabricated lightweight element was used as the strip foundation and the base of a building with a double-brick exterior wall, the outer insulation needed to be extended if not keeping an indoor temperature at $20{ }^{\circ} \mathrm{C}$. Keeping the indoor temperature at 20 ${ }^{\circ} \mathrm{C}$, where the EPS element was used as the strip foundation and the base of a building with a wood-stud exterior wall, it was sufficient with an outer EPS insulation, $0.1 \mathrm{~m}$ thick and extending $0.42 \mathrm{~m}$ in front of the outer plinth only $0.15 \mathrm{~m}$ under the finished ground surface in order to keep the soil immediately beneath the gravel layer in the vicinity of a corner of the building from freezing during a cold winter. However, if the indoor temperature was kept equal to the outdoor temperature but not lower than $5^{\circ} \mathrm{C}$, it was sufficient with an

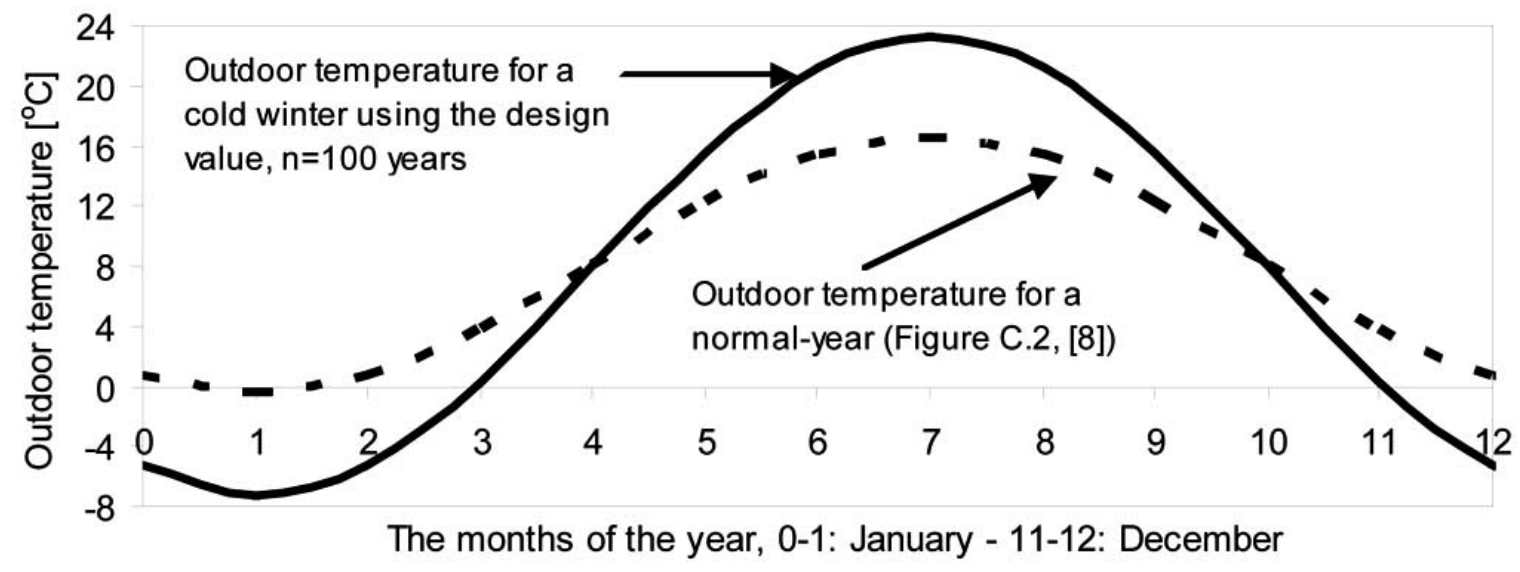

Fig. (4). Variation of the monthly outdoor mean temperature for a normal year and for a cold year in Denmark. 
outer EPS insulation that was $0.1 \mathrm{~m}$ thick and extended 0.7 $\mathrm{m}$ in front of the outer plinth only $0.15 \mathrm{~m}$ under the finished ground surface in order to keep the soil immediately beneath the gravel layer in the vicinity of a corner of the building from freezing during a cold winter. If the indoor temperature was kept equal to the outdoor temperature, an outer EPS insulation $(0.1 \mathrm{~m}$ thick and extending $0.9 \mathrm{~m}$ in front of the outer plinth and only $0.15 \mathrm{~m}$ under the finished ground surface) was able to keep the soil immediately beneath the gravel layer in the vicinity of a corner of a building from freezing during a cold winter. It is recommended that the vicinity of the corner should include the area, in the ground, in front of the corner and the area along the facade of a building, at least, covering the extra length of outer insulation.

\section{CONSTRUCTING THE STRIP FOUNDATION OF EPS ON SITE}

At most locations in Denmark a stable ground of glacial deposits (moraine) is found beneath a top-soil layer ap- proximately 0.2 to $0.4 \mathrm{~m}$ thick. The top-soil layer was removed from an area covering the area of the building. Material at least down to a depth of $0.35 \mathrm{~m}$ beneath the top-soil surface had to be dug up. The excavated area was then covered with a $0.1 \mathrm{~m}$ capillary breaking layer of gravel, which was stamped in order to form the stable base for the building. Temperature measurement points were mounted on top of the gravel layer and the prefabricated elements were mounted on top as the strip foundation, (see Fig. 5a)). Mounting the strip foundation, elements were held together with large plastic securing clips and supported on the exterior, and on the interior $0.3 \mathrm{~m}$ of EPS in two layers was mounted, in the finished building, to serve as insulation beneath the concrete floor slab, (see Fig. 5b)). Before casting the concrete, iron mesh reinforcement was mounted which prevented the development of shrinkage cracking inside the strip foundation, as well as wires along the moat formed by the two vertical EPS boards in the prefabricated elements. Stainless steel rods, $5 \mathrm{~mm}$ in diameter were put through the inner vertical boards of the prefabricated EPS elements every

$\mathbf{a}$

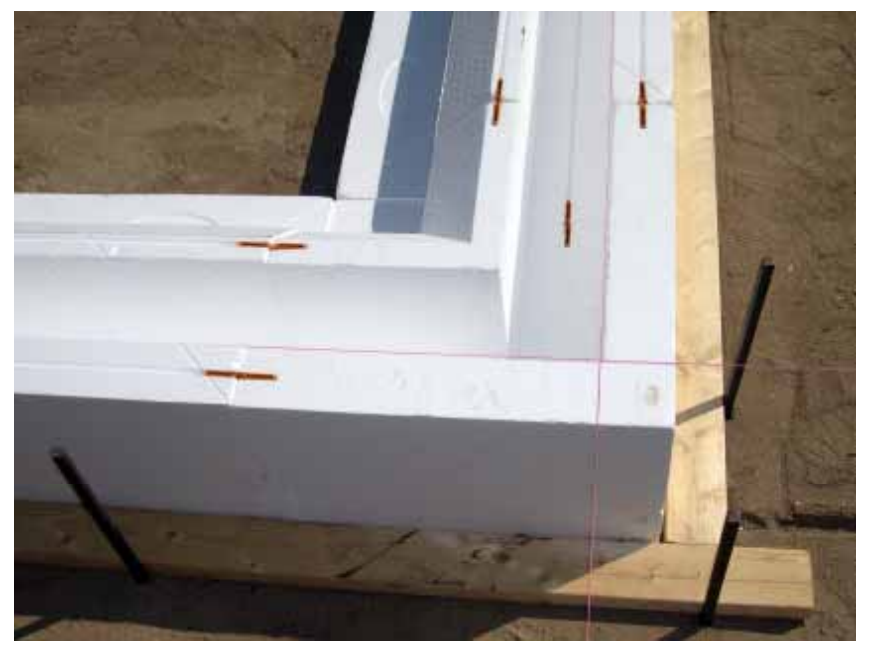

b

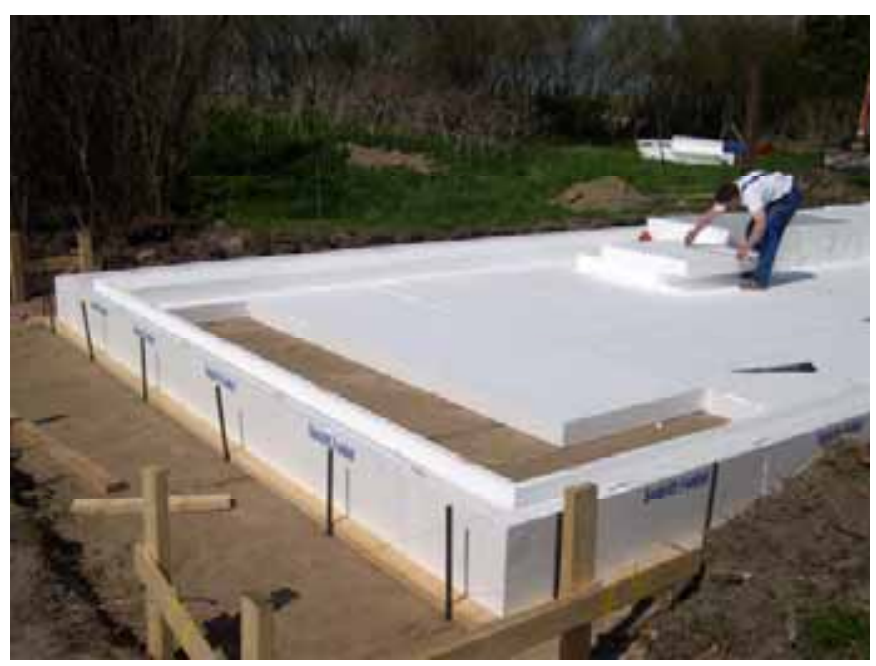

Fig. (5). a): prefabricated EPS elements mounted as the strip foundation and held together with large plastic securing clips, b: $0.3 \mathrm{~m}$ EPS, mounted as two layers on top of the base of stamped gravel bordered by the strip foundation, serving as the insulation layer beneath the concrete slab. 
$0.6 \mathrm{~m}$, in order to attach the concrete in the moat to the concrete floor slab. Concrete was cast and leveled. After a few hours, when the concrete was stable in shape, the outer vertical EPS boards of the prefabricated EPS elements were removed, thus exposing the outer surface of the concrete moat as the outer plinth. The removed outer vertical EPS boards were used as the outer insulation in front of and around the outer plinth.

On site, temperatures were observed at locations in the zone between the capillary break layer of gravel and the layer of EPS. Temperature measurements were made at measurement points located along two straight lines for the prefabricated lightweight element used as the strip foundation and the base of the building with a traditional doublebrick exterior wall; the building that had a traditional woodstud exterior wall. Temperature measurements were carried out beneath one room of the building.

Temperature measurements were made for the doublebrick exterior wall. Firstly, along a line starting at the north/eastern corner under the strip foundation at the outer plinth and stretching horizontally onwards from this point at a $45^{\circ}$ angle beneath the building. Temperature measurement points were positioned along the straight line at $0 ; \sqrt{2} 0.2$; $\sqrt{2} 0.5 ; \sqrt{2}$ and at $\sqrt{2} 2 \mathrm{~m}$ from the outer plinth. Secondly, along a line starting $3 \mathrm{~m}$ from the north/eastern corner along the side of the building facing east, under the strip foundation at the outer plinth and onwards from this point along a straight line at a $90^{\circ}$ angle horizontally, beneath the building. Temperature measurement points were positioned along the straight line $0 ; 0.2 ; 0.5$; at 1 and $2 \mathrm{~m}$ from the outer plinth. In addition the temperature of the concrete floor slab of the building was measured at four points along the two straight lines, where temperatures were measured, just above the measurement point located at: $\sqrt{2} 0.5 \mathrm{~m}$ and $\sqrt{2} 2 \mathrm{~m}$ from the outer plinth on the first line and above the measurement point located 0.5 and $2 \mathrm{~m}$ from the outer plinth on the second line. Furthermore the soil temperature was measured at $2 \mathrm{~m}$ from the north/eastern corner along the side of the building facing east in front of the strip foundation $0.2 \mathrm{~m}$ from the outer plinth and approximately $0.4 \mathrm{~m}$ below the finished ground level, (see Fig. 6).

For the wood-stud exterior wall, temperature measurements were made. Firstly, along a line starting at the north/western corner under the strip foundation at the outer plinth and stretching horizontally onwards from this point at a $45^{\circ}$ angle, beneath the building. Temperature measurement points were positioned along the straight line $0 ; \sqrt{2}$ and at $\sqrt{2} 2 \mathrm{~m}$ from the outer plinth. Secondly, along a line starting $3 \mathrm{~m}$ from the north/western corner along the side of the building facing west, under the strip foundation at the outer plinth and stretching horizontally onwards from this point along a straight line at a $90^{\circ}$ angle, beneath the building. Temperature measurement points were positioned along the straight line 0,1 and at $2 \mathrm{~m}$ from the outer plinth. In addition the temperature of the concrete floor slab of the building was observed at two points along the two straight lines, where temperatures were measured, one located $\sqrt{2} 0.3 \mathrm{~m}$ from the outer plinth above the first line and one above the measurement point located $2 \mathrm{~m}$ from the outer plinth on the second line. Furthermore the soil temperature was measured at $2 \mathrm{~m}$ from the north/western corner along the side of the building facing north in front of the strip foundation $0.2 \mathrm{~m}$ from the outer plinth approximately $0.4 \mathrm{~m}$ below the finished ground level, (see Fig. 7).

\section{HEAT FLOW AND TEMPERATURE IN THE STRIP- FOUNDATION ELEMENT}

Fig. (8) shows the calculated temperature, isotherm curves and the heat flow for the prefabricated lightweight element used as the strip foundation. The overall coefficient of heat transmission of the exterior wall was equal to 0.2 $\mathrm{W} / \mathrm{m}^{2} \mathrm{~K}$. Calculations were made for a building with conven-
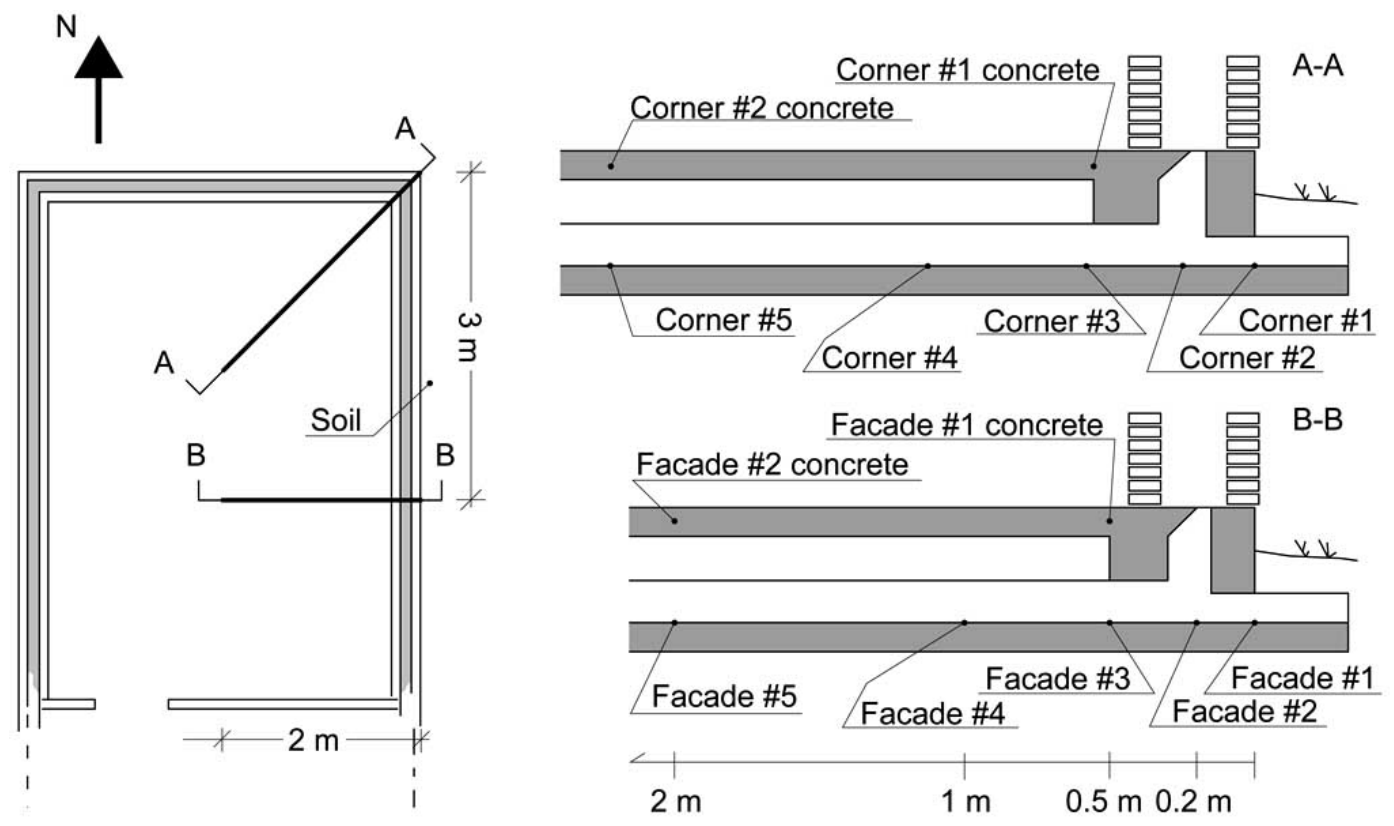

Fig. (6). Position of temperature measurement points located beneath the building constructed with a double-brick exterior wall. 

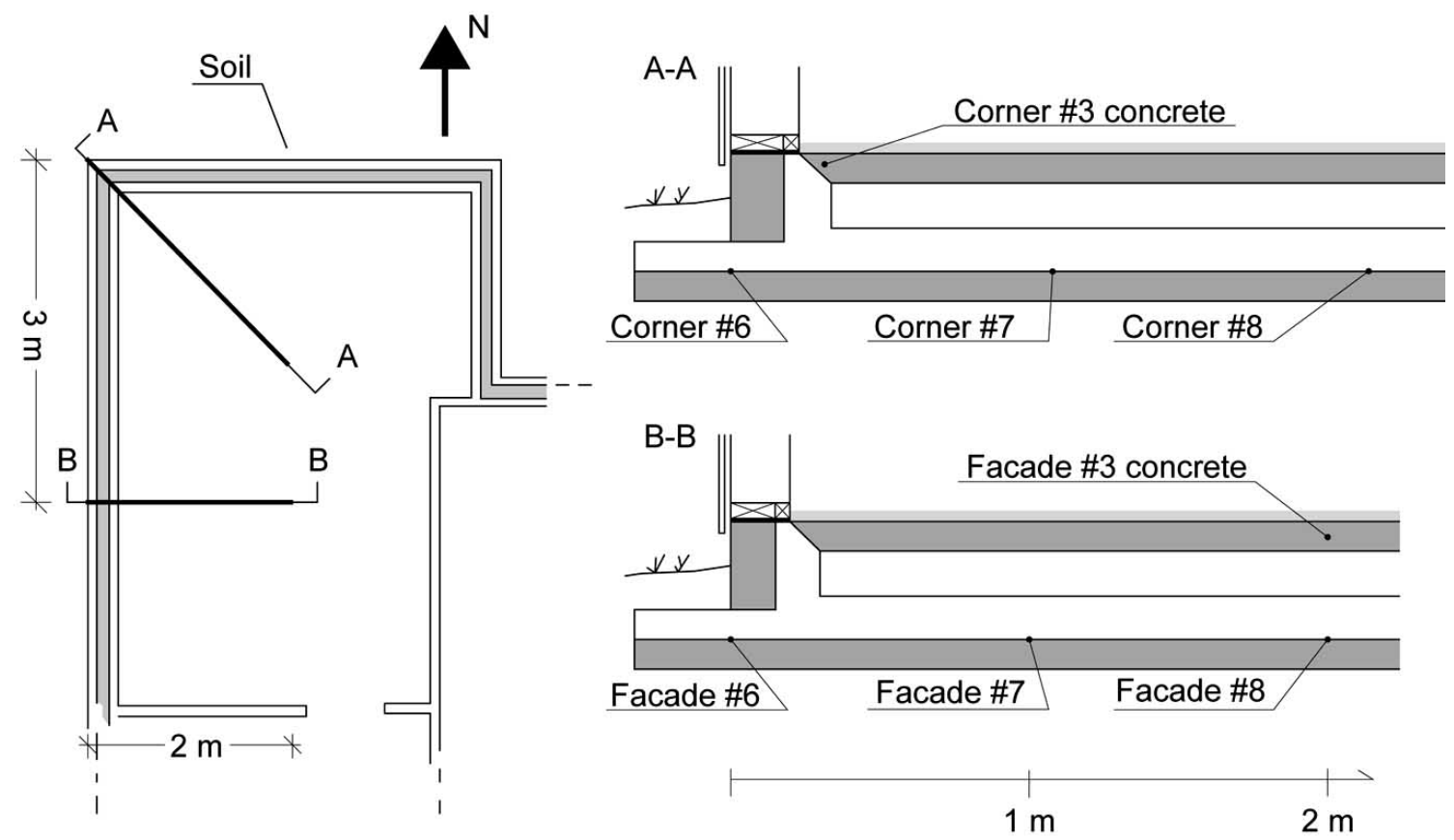

Fig. (7). Position of temperature measurement points located beneath the building constructed with a wood-stud exterior wall.

tional heating and for an outdoor temperature of $0{ }^{\circ} \mathrm{C}$ and an indoor temperature of $20^{\circ} \mathrm{C}$. Arrows show the heat flow and the length of the arrows visualizes the relative size of the heat flow. Isotherm curves, in steps of $2{ }^{\circ} \mathrm{C}$, are drawn as continuous lines with fixed indications of the temperature of the individual curve.

\section{TEMPERATURES CALCULATED AT MEASURE- MENT POINTS}

The outdoor temperature has an impact on the temperature at the measurement points between the capillary breaking layer of gravel and the layer of EPS beneath the building. Table $\mathbf{1}$ and Table $\mathbf{2}$ show the lowest temperatures calculated at the measurement points. Table 1 shows the measurement points facing the side facing east, for a building with a double-brick exterior wall separated by mineral fiber insulation. Table 2 shows the measurements points facing the westfacing side, for a building with a wood-stud wall with mineral fiber insulation as the exterior wall. Calculations were carried out for i) a constant indoor temperature of $20{ }^{\circ} \mathrm{C}$, ii) a lowest indoor temperature of $5{ }^{\circ} \mathrm{C}$ and iii) for an indoor temperature equivalent to the outdoor temperature. Calculations were carried out for a building with a traditional wood-stud wall with mineral fiber insulation as the exterior wall and a building with a double-brick exterior wall separated by mineral fiber insulation.

\section{RESULTS}

\section{Embedded Temperature}

Results from temperature measurements on site between the capillary break layer of gravel and the layer of EPS beneath the two buildings are shown in Fig. (9) to Fig. (14). Figs. (9-11) show temperature measurements for the building with a double-brick exterior wall separated by mineral fiber insulation. Figs. (12-14) show temperature measurements for the building with a wood-stud wall with mineral fiber insulation as the exterior wall. Measurements are shown as mean values of measurements made over a 6-hour period.

Fig. (9) shows temperature measurements at 5 positions along the line that starts at the north/eastern corner, and stretches from under the strip foundation at the outer plinth and onwards from this point at a $45^{\circ}$ angle beneath the building, in the following referred to as Corner \#1, Corner \#2, Corner \#3, Corner \#4 and Corner \#5 respectively, positioned along the straight line at $0 ; \sqrt{2} 0.2 ; \sqrt{2} 0.5 ; \sqrt{2}$ and at $\sqrt{2}$ $2 \mathrm{~m}$ from the outer plinth. Fig. (10) shows temperature measurements at 5 positions along the line that starts $3 \mathrm{~m}$ from the north/eastern corner along the side of the building facing east. It stretches from under the strip foundation at the outer plinth and onwards from this point at a $90^{\circ}$ angle beneath the house, in the following referred to as Facade \#1, Facade \#2, Facade \#3, Facade \#4, Facade \#5 respectively, positioned along the straight line at $0 ; 0.2 ; 0.5 ; 1$ and at $2 \mathrm{~m}$ from the outer plinth. Results from temperature measurements on site within the concrete floor slab of the building and within the soil are shown in Fig. (11). The measurements at the 4 positions within the concrete floor slab vertically above the positions Corner \#3, Corner \#5, Facade \#3 and Facade \#5 are in the following referred to as Corner \#1 concrete, Corner \#2 concrete, Facade \#1 concrete and Facade \#2 concrete, respectively. In the following, measurement of the soil temperature is referred to as Soil. Unfortunately the data logger broke down and was unable to make temperature measurements in the period from 24 October to 27 November 2006 and again in the period from 21 January to 9 February 2007.

Fig. (12) shows temperature measurements at 3 positions along the line that starts at the north/western corner, continues under the strip foundation, at the outer plinth and stretches onwards from this point beneath the house at a $45^{\circ}$ 
a

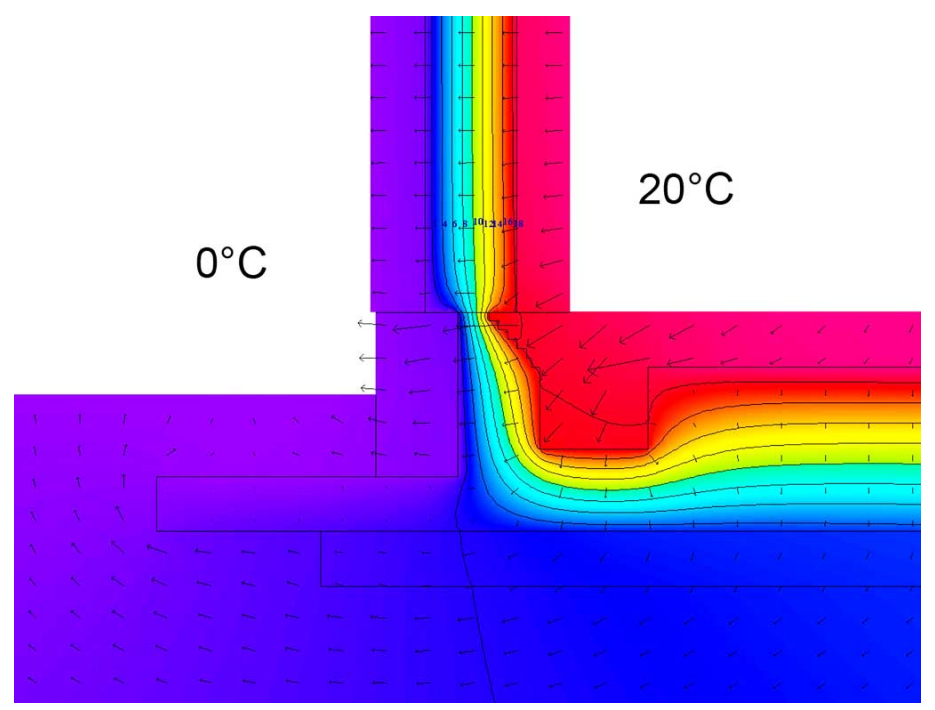

b

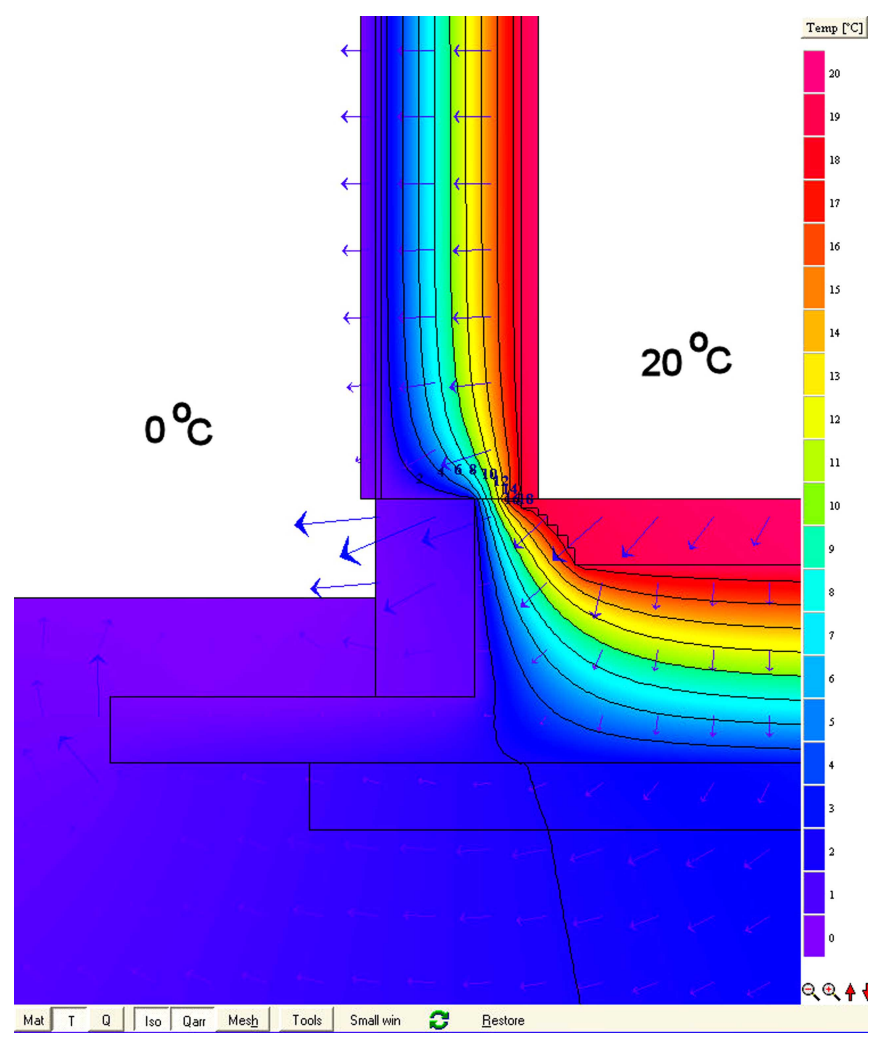

Fig. (8). Temperature, isotherm curves and the heat flow through the prefabricated lightweight element used as strip foundation and the base of building with a traditional a): double-brick exterior wall or b): wood-stud exterior wall, with mineral fiber insulation.

angle, in the following referred to as Corner \#6, Corner \#7, and Corner \#8 respectively, positioned along the straight line $0 ; \sqrt{2}$ and at $\sqrt{2} 2 \mathrm{~m}$ from the outer plinth. Fig. (13) shows temperature measurements at 3 positions along the line that starts $3 \mathrm{~m}$ from the north/western corner along the westfacing side of the building, and continues under the strip foundation at the outer plinth and onwards from this point beneath the building at a $90^{\circ}$ angle, in the following referred to as Facade \#6, Facade \#7, and Facade \#8 respectively, positioned along the straight line at $0 ; 1$ and at $2 \mathrm{~m}$ from the outer plinth. Results of temperature measurements on site within the concrete floor slab of the building and within the soil are shown in Fig. (14). In the following the measurements at the 2 positions within the concrete floor slab vertically above the two lines, one positioned $\sqrt{2} 0.3 \mathrm{~m}$ from the outer plinth above the first line and the other positioned above the measurement point referred to as Facade \#8, are referred to as Corner \#3 concrete and Facade \#3 concrete, respectively; measurement of the soil temperature is referred to as Soil. 
Table 1. Lowest Temperatures Calculated at the Measurement Points Facing the Side of the Building with the Double-Brick Exterior Wall Facing East. Measurement Points were Positioned Under the Strip Foundation and Stretching from Under the Outer Plinth and Onwards from this Point Underneath the House at a 90 ${ }^{\circ}$ Angle, Along a Straight Line at 0; 0.2; 0.5; 1 and at $2 \mathrm{~m}$ Referred to as Facade \#1, Facade \#2, Facade \#3, Facade \#4, Facade \#5, respectively

\begin{tabular}{llllllc} 
Measurement points & Facade \#1 & Facade \#2 & Facade \#3 & Facade \#4 & Facade \#5 & Inside \\
\hline i) Normal year & $5.0^{\circ} \mathrm{C}$ & $6.0^{\circ} \mathrm{C}$ & $7.2^{\circ} \mathrm{C}$ & $8.4^{\circ} \mathrm{C}$ & $9.9^{\circ} \mathrm{C}$ & $20^{\circ} \mathrm{C}$ \\
ii) Normal year & $4.0^{\circ} \mathrm{C}$ & $4.7^{\circ} \mathrm{C}$ & $5.5^{\circ} \mathrm{C}$ & $6.4^{\circ} \mathrm{C}$ & $7.5^{\circ} \mathrm{C}$ & $>5{ }^{\circ} \mathrm{C}$ \\
iii) Normal year & $3.8^{\circ} \mathrm{C}$ & $4.4^{\circ} \mathrm{C}$ & $5.1^{\circ} \mathrm{C}$ & $5.9^{\circ} \mathrm{C}$ & $6.9{ }^{\circ} \mathrm{C}$ & Outdoor \\
i) Cold year & $1.7^{\circ} \mathrm{C}$ & $3.2^{\circ} \mathrm{C}$ & $4.1^{\circ} \mathrm{C}$ & $6.9^{\circ} \mathrm{C}$ & $9.3^{\circ} \mathrm{C}$ & $20^{\circ} \mathrm{C}$ \\
ii) Cold year & $0.7^{\circ} \mathrm{C}$ & $1.9^{\circ} \mathrm{C}$ & $3.4^{\circ} \mathrm{C}$ & $5.1^{\circ} \mathrm{C}$ & $7.0^{\circ} \mathrm{C}$ & $>5^{\circ} \mathrm{C}$ \\
iii) Cold year & $0.2^{\circ} \mathrm{C}$ & $1.2^{\circ} \mathrm{C}$ & $2.4^{\circ} \mathrm{C}$ & $3.9^{\circ} \mathrm{C}$ & $5.7^{\circ} \mathrm{C}$ & Outdoor \\
\hline
\end{tabular}

Table 2. Lowest Temperatures Calculated at the Measurement Points Facing the West-Facing Side of the Building with a Traditional Wood-Stud Wall with Mineral Fiber Insulation as the Exterior Wall. Measurement Points were Positioned Under the Strip Foundation and Stretching from Under the outer Plinth and Onwards from these Points Beneath the House at a $90^{\circ}$ Angle Along a Straight Line at $0 ; 1$ and at $2 \mathrm{~m}$ Referred to as Facade \#6, Facade \#, Facade \#8, Respectively

\begin{tabular}{lllll}
\hline Measurement points & Facade \#6 & Facade \#7 & Facade \#8 & Inside \\
\hline i) Normal year & $4.9^{\circ} \mathrm{C}$ & $8.3^{\circ} \mathrm{C}$ & $9.8^{\circ} \mathrm{C}$ & $20{ }^{\circ} \mathrm{C}$ \\
ii) Normal year & $4.0{ }^{\circ} \mathrm{C}$ & $6.4{ }^{\circ} \mathrm{C}$ & $7.5^{\circ} \mathrm{C}$ & $\geq 5{ }^{\circ} \mathrm{C}$ \\
iii) Normal year & $3.8^{\circ} \mathrm{C}$ & $5.9^{\circ} \mathrm{C}$ & $6.9{ }^{\circ} \mathrm{C}$ & Outdoor \\
i) Cold year & $1.5{ }^{\circ} \mathrm{C}$ & $6.8{ }^{\circ} \mathrm{C}$ & $9.2{ }^{\circ} \mathrm{C}$ & $20^{\circ} \mathrm{C}$ \\
ii) Cold year & $0.7{ }^{\circ} \mathrm{C}$ & $5.0^{\circ} \mathrm{C}$ & $7.0^{\circ} \mathrm{C}$ & $\geq 5{ }^{\circ} \mathrm{C}$ \\
iii) Cold year & $0.2{ }^{\circ} \mathrm{C}$ & $3.9^{\circ} \mathrm{C}$ & $5.7{ }^{\circ} \mathrm{C}$ & Outdoor \\
\hline
\end{tabular}

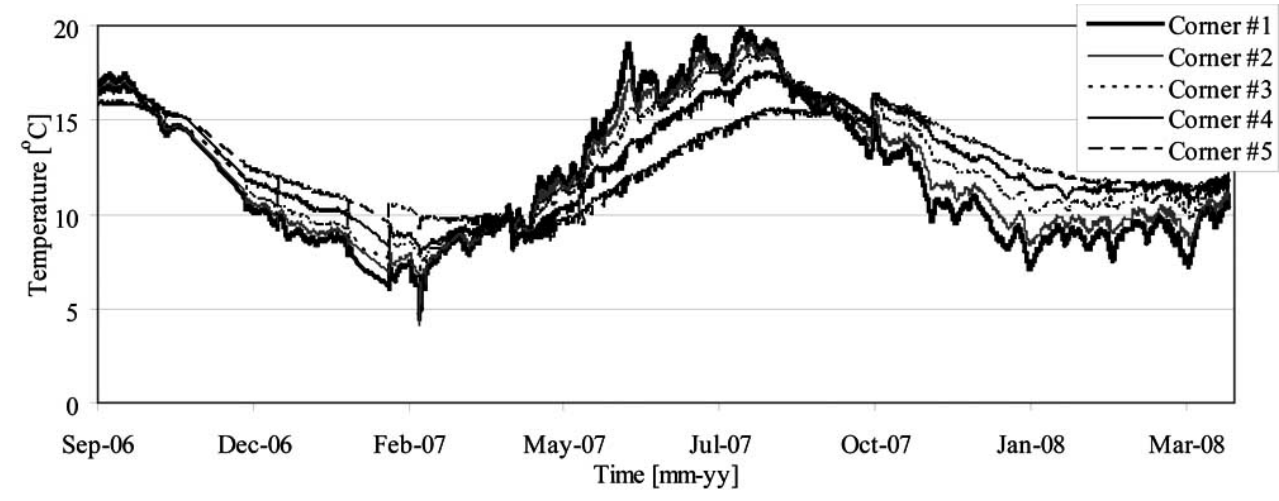

Fig. (9). Temperature measurements at 5 positions along the line that starts at the north/eastern corner, and stretches from under the strip foundation at the outer plinth and onwards from this point beneath the building at a $45^{\circ}$ angle.

\section{Air Temperature}

The temperature was measured at shady locations outside as well as inside the two houses. Results of the temperature measurements are shown in Fig. (15). Measurements made in the period from 12 September 2006 to 17 April 2008 were made at the side of the house with an exterior wall constructed as a traditional double-brick wall. Measurements made in the period from 8 November 2007 to 9 May 2009 were made at the side of the house with an exterior wall constructed as a traditional wood-stud wall. Measurements are shown as mean values of measurements made over a 6-hour period.

\section{SUMMARY AND DISCUSSION}

The performance of a new prefabricated lightweight element to be used as a strip foundation forming the base of a small residential building was assessed on site. The element was assessed on site for use as a strip foundation and the base of a building with a double-brick exterior wall and a building with a wood-stud exterior wall. The lightweight elements were made of expanded polystyrene. The elements were produced and shaped as one coherent element, as units $1.2 \mathrm{~m}$ long and $0.6 \mathrm{~m}$ wide. The assessment of performance was based on observations of the handling of the element on site as well as measurements of temperature conditions at measurement points positioned at the outer plinth and stretching onwards from these points beneath two small residential building. In addition the soil temperature, the temperature within the concrete floor slab and the outdoor as well as the indoor temperatures were measured. Recording of outdoor temperature at locations in the shadow showed "normal" Danish weather conditions throughout the period of investigation. However, the mean temperatures in November 


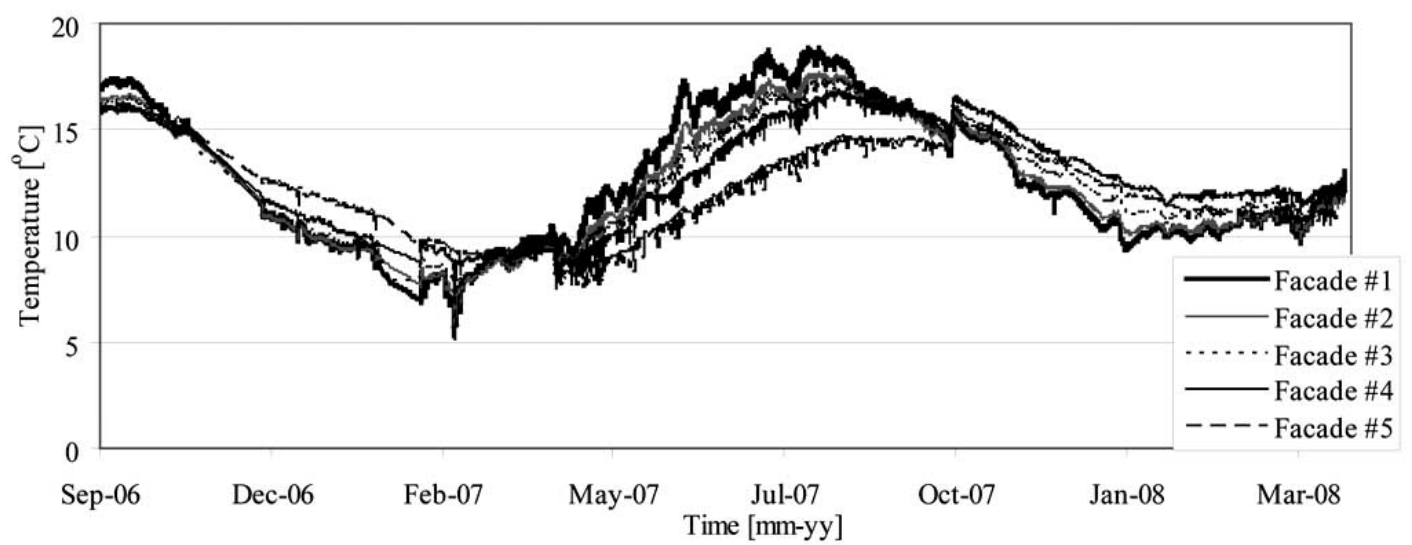

Fig. (10). Temperature measurements at 5 positions along a line that starts $3 \mathrm{~m}$ from the north/eastern corner along the east-facing side of the building, and stretches from under the strip foundation at the outer plinth and onwards from this point beneath the building at a $90^{\circ}$ angle.

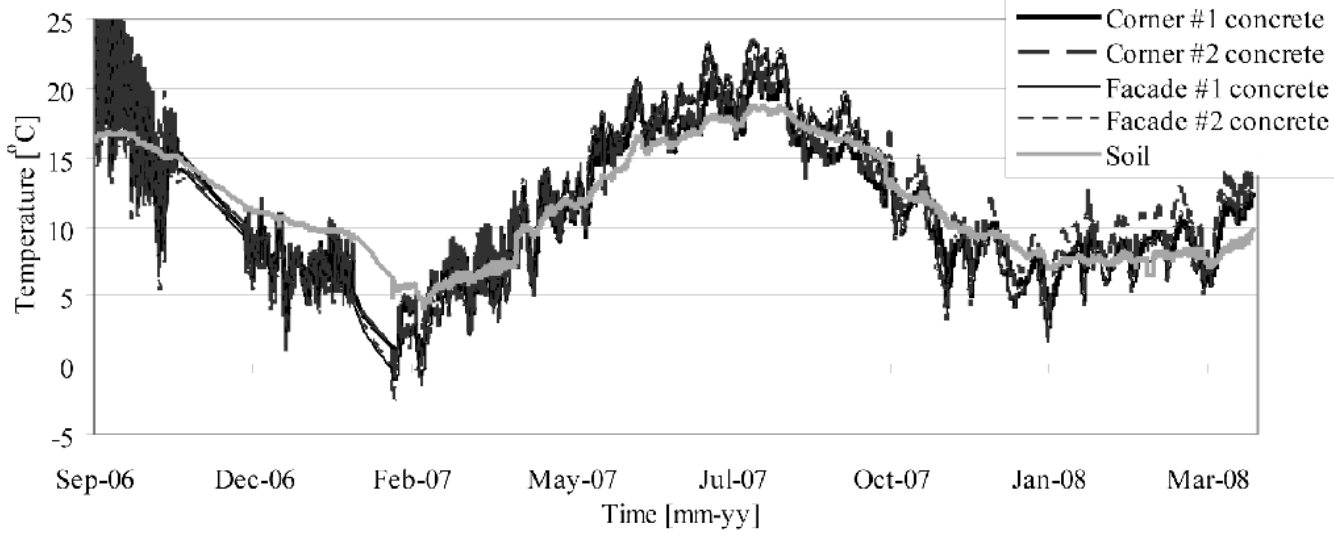

Fig. (11). Temperature measurements within the concrete floor slab of the building and in the soil. Measurements at the 4 positions within the concrete floor slab vertically above the positions Corner \#3, Corner \#5, Facade \#3 and Facade \#5 referred to as Corner \#1 concrete, Corner \#2 concrete, Facade \#1 concrete and Facade \#2 concrete, respectively.

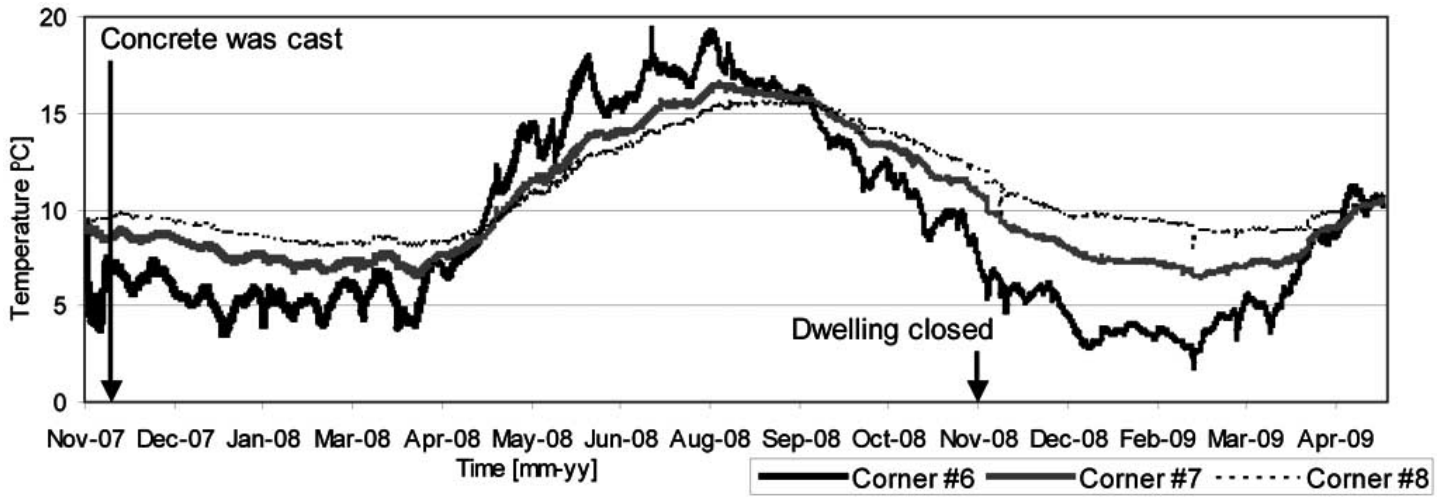

Fig. (12). Temperature measurements at 3 positions along the line that starts at the north/western corner, and continues from under the strip foundation at the outer plinth and stretches onwards from this point beneath the building at a $45^{\circ}$ angle.

vember and December 2008 and April 2009 were in the high range in Danish climate records. Both buildings were under construction throughout the period of investigation. The indoor temperatures were measured from the time when the individual buildings were mounted with windows and doors that could be closed and the buildings could be heated. Only the small residential building with an exterior wall con- structed as a traditional wood-stud wall was heated during the period of examination.

\section{Design of Elements}

The EPS element was specially designed to form a strip foundation that could be integrated into the insulation material positioned beneath the concrete floor slab. By integrating 


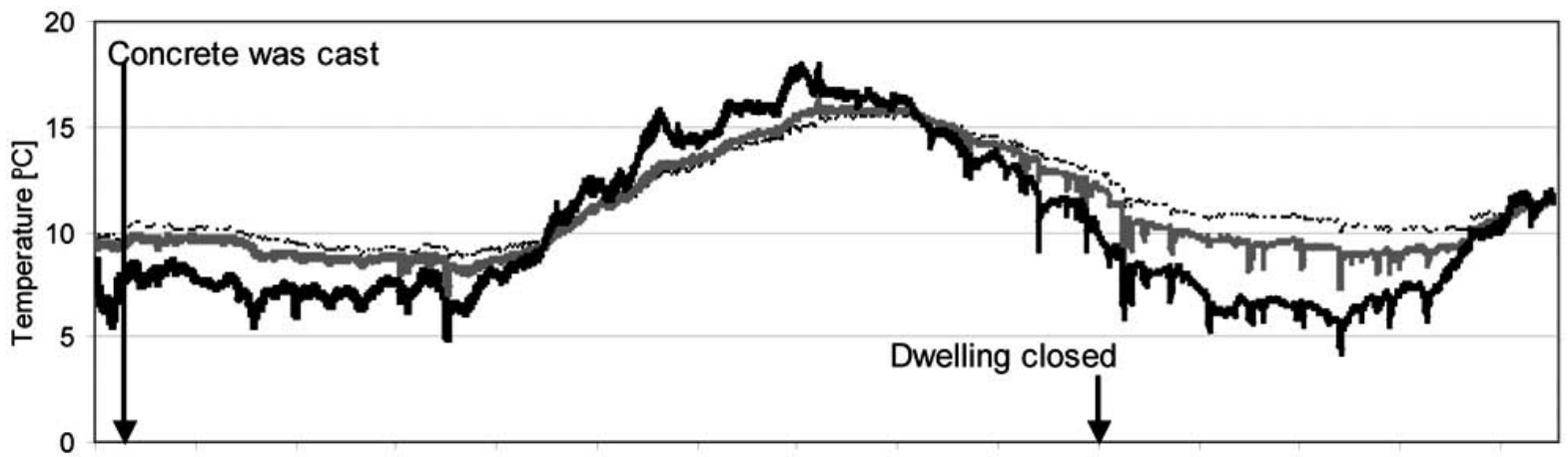

Nov-07 Dec-07 Jan-08 Mar-08 Apr-08 May-08 Jun-08 Aug-08 Sep-08 Oct-08 Nov-08 Dec-08 Feb-09 Mar-09 Apr-09 Time [mm-yy]

Facade \#6

Facade \#7 $\quad \cdots \cdot$.... Facade \#8

Fig. (13). Temperature measurements at 3 positions along a line that starts $3 \mathrm{~m}$ from the north/western corner along the west-facing side of the building, and continues from under the strip foundation at the outer plinth and stretches onwards from this point beneath the house at a $90^{\circ}$ angle.

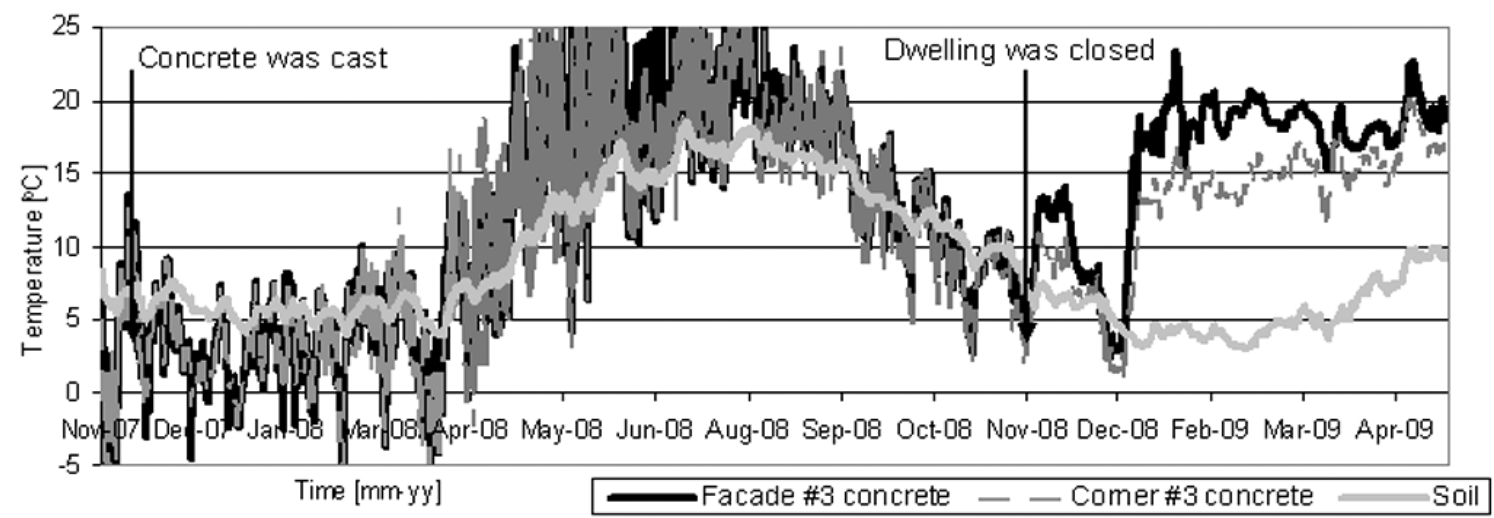

Fig. (14). Temperature measurements within the concrete floor slab of the building and in the soil. Measurements at 2 positions within the concrete floor slab vertically above the two lines, one positioned $\sqrt{2} 0.3 \mathrm{~m}$ from the outer plinth above the first line and the other positioned above the measurement point Facade \#8, are referred to as Corner \#3 concrete and Facade \#3 concrete, respectively.

the insulation material beneath the concrete floor slab through the strip foundation to the insulation material in the exterior wall, the strip foundation thus constitutes a full and continuous insulation cover against the heated part of the building. By applying a principle for the strip foundation that results in a full and continuous insulation cover against the heated part of the building, very little energy is allowed to be lost through the joint between the concrete floor slab and the exterior wall.

The EPS element was specially designed to form the strip foundation that together with the ground floor slab represent the base of a small residential building with an exterior wall constructed as a traditional double-brick wall, a traditional wood-stud wall, or combinations of lightweight concrete, brick and wood-stud walls with insulation.

The prefabricated EPS element complies in practice with the requirements of low energy consumption required in the new Danish Building Regulations [7]. In practice buildings that use heating in the concrete floor slab must minimize the heat loss through the foundation element and normally not exceed a surplus heat loss of $0.12 \mathrm{~W} / \mathrm{mK}$. When using conventional heating in the building, the surplus heat loss must not exceed $0.15 \mathrm{~W} / \mathrm{mK}$. Within these parameters, the overall coefficient of heat transmission of the ground floor slab and the exterior wall must be equal to or less than $0.12 \mathrm{~W} / \mathrm{m}^{2} \mathrm{~K}$ and $0.2 \mathrm{~W} / \mathrm{m}^{2} \mathrm{~K}$, respectively. The element used as the strip foundation of the small residential building with an exterior wall constructed as a double-brick exterior wall met the heatloss requirements when using conventional heating in the building. The surplus heat loss through the foundation element was calculated to be $0.13 \mathrm{~W} / \mathrm{mK}$ increasing to 0.14 $\mathrm{W} / \mathrm{mK}$ when using heating in the concrete floor slab. The surplus heat loss through the foundation element increased as the temperature in the block of concrete underneath the inner brick wall of the exterior wall increased and caused increased heat flow, especially at the less insulated areas towards the exterior wall, (see Fig. 8a)). By eliminating the block of concrete underneath the exterior wall and allowing the strip foundation to support a wood-stud wall with mineral fiber insulation as the exterior wall, the surplus heat loss through the foundation element was lowered to $0.09 \mathrm{~W} / \mathrm{mK}$ not depending on whether using heating in the concrete floor slab nor using conventional heating in the building.

Ensuring that there is stable, non-freezing ground underneath a building is necessary for maintaining structural stability and avoiding settling cracks during cold winters. In order to ensure stability of the strip foundation, temperatures below $-1{ }^{\circ} \mathrm{C}$ must not occur in any layer susceptible to frost underneath the building [12]. Along the facade, outer insulation of EPS, $0.1 \mathrm{~m}$ thick and extending $0.4 \mathrm{~m}$ in front of the 
outer plinth and just $0.15 \mathrm{~m}$ under the finished ground surface, proved sufficient insulation to keep the soil just beneath the gravel layer from freezing.

In the vicinity of the corners of the double-brick building, no extra insulation was needed when the indoor temperature was kept at $20{ }^{\circ} \mathrm{C}$. At the vicinity of a corner where the prefabricated lightweight element was used as the strip foundation and the base of a, building with a wood-stud exterior wall, it was sufficient with an outer EPS insulation extending $0.42 \mathrm{~m}$ in front of the outer plinth in order to keep the soil immediately beneath the gravel layer in the vicinity of a corner of a building from freezing during a cold winter. However, when decreasing, the required indoor temperature to a minimum of $5{ }^{\circ} \mathrm{C}$, it was necessary to use outer EPS insulation that was $0.1 \mathrm{~m}$ thick and extended $0.7 \mathrm{~m}$ in front of the outer plinth at just $0.15 \mathrm{~m}$ below the finished ground surface. To keep the indoor temperature equivalent to the outdoor temperature, it was necessary to use outer EPS insulation that was $0.1 \mathrm{~m}$ thick and extended $0.9 \mathrm{~m}$ in front of the outer plinth at just $0.15 \mathrm{~m}$ below the finished ground surface.

\section{Performance on Site}

The investigation covered a real life situation and the use of a newly designed element as the strip foundation of two small residential buildings, in this case two single-family houses. The performance of the element was observed and recorded on site. Ground conditions at the building sites consisted of a stable ground of glacial deposit (moraine) underneath the top soil layer. The top soil layer was removed with a mechanical mini-excavator in an area that comprised the base of the buildings, including the area for the outer insulation. The areas of the base of the buildings were excavated to a depth of $0.35 \mathrm{~m}$ below the top soil surface. The excavated area was then covered with a $0.1 \mathrm{~m}$ capillary break layer of gravel and stamped to obtain a stable base for the buildings individualy. Hereafter the prefabricated elements were mounted on top of the gravel as the strip foundation and fasted with large plastic securing clips and an outer support was established. A layer of insulation was mounted inside the strip foundation serving as insulation underneath the concrete floor slab. The elements were designed to be able to be handled on site by one man, and proved to be so. At the end of the first day iron mesh reinforcement was mounted inside the strip foundation, which prevented shrinkage crack development, and mounted as wires along the moat formed by the two vertical boards of EPS in the prefabricated elements. Stainless steel rods were placed to form the mechanical fastening points for the concrete for the outer plinth and the concrete floor slab. At the beginning of the second day concrete was cast and leveled. After a few hours, when the concrete was stable in shape, the outer vertical boards of the prefabricated elements of EPS were removed, exposing the outer surface of the concrete moat as the outer plinth. The removed outer vertical boards of EPS were mounted as the outer insulation and covered to protect them from being damaged during the later construction phases of the building. The base of the buildings were cast in one working operation and completed within two working days.

\section{Measured Temperatures}

Temperatures were measured at measurement points positioned at the outer plinth and continued from under the strip foundation at the outer plinth and stretching onwards from these points beneath each of the buildings. In addition the soil temperature, the temperature within the concrete floor slab and temperatures outdoors and indoors were measured for each of the buildings.

The measured outdoor and indoor temperatures are shown in Fig. (15). Temperature measurements were found to vary a lot from day to day. However, temperature measurements for the small residential building with an exterior wall constructed as a traditional double-brick wall showed a period with a fairly stable outdoor temperature of $-1.2{ }^{\circ} \mathrm{C}$ in late February 2007. The temperature measured during the same period was $5{ }^{\circ} \mathrm{C}$ at the outer plinth under the strip foundation of the facade. This resulted in a mean tempera-

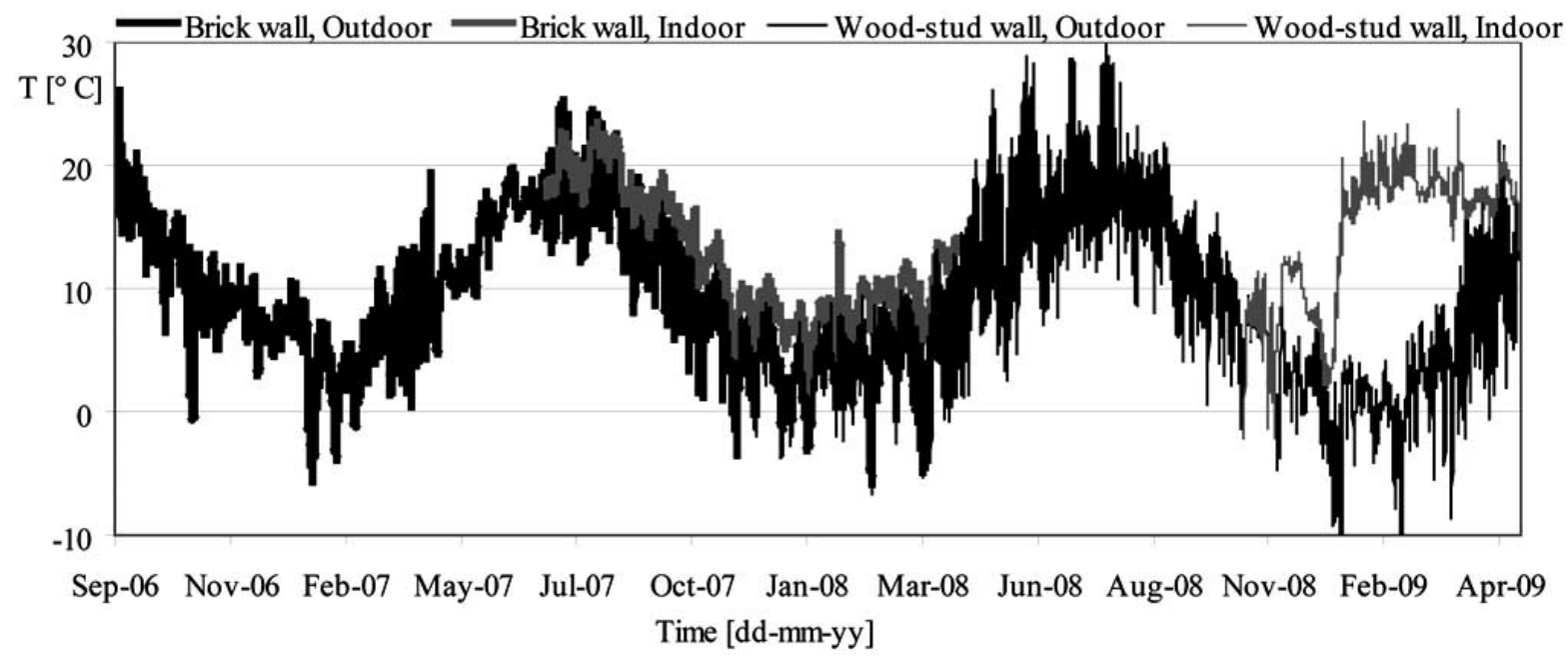

Fig. (15). Temperature measurements at two different shady locations at the side where, the EPS element was used as the strip foundation and the base of a small residential building with a double-brick exterior wall and where the EPS element was used as the strip foundation and the base of a small residential building with a wood-stud exterior wall . Measurements are shown as mean values of measurements made over a 6-hour period. 
ture difference of $6.2{ }^{\circ} \mathrm{C}$ between the outdoor temperature and the temperature under the strip foundation at the outer plinth. Calculations of the lowest temperature under the strip foundation of the facade are shown in Table $\mathbf{1}$. The calculated difference between the temperature under the strip foundation at the outer plinth and the outdoor temperature was $4.3{ }^{\circ} \mathrm{C}$ for a normal year when the indoor temperature is equal to the outdoor temperature. The method outlined for determining the temperature in the ground underneath a building was calculated to be $1.9^{\circ} \mathrm{C}$ lower than measured on site.

Temperature measurements for the small residential building with an exterior wall constructed as a traditional wood-stud wall showed a period with a fairly stable outdoor temperature for a normal year in late January and February 2009 and $20^{\circ} \mathrm{C}$ inside. The temperature measured during the same period was $5.5^{\circ} \mathrm{C}, 9.3{ }^{\circ} \mathrm{C}$ and $10.5{ }^{\circ} \mathrm{C}$ for Facade \#6, Facade \#7 and Facade \#8, respectively. The lowest calculated temperatures for Facade \#6, Facade \#7 and Facade \#8 was $4.9^{\circ} \mathrm{C}, 8.3{ }^{\circ} \mathrm{C}$ and $9.8^{\circ} \mathrm{C}$, respectively, (see Table 2 ).

The method outlined follows the principles stipulated by Danish Standard [8, 12]. Experience gained by similar calculations carried out for other types of foundation dug at a lower depth showed that the difference in temperature along the facade of a building and at the vicinity of a corner of a building was approximately $2.6{ }^{\circ} \mathrm{C}$. The temperature was calculated to be higher along the facade of a building compared with temperatures calculated at the vicinity of a corner of a building. Temperature measurements showed that the difference in temperature along the facade of the building and at the vicinity of the corner of the building was $1.2{ }^{\circ} \mathrm{C}$ for the building with an exterior wall constructed as a traditional double-brick wall, and $2.8{ }^{\circ} \mathrm{C}$ for the building with an exterior wall constructed as a traditional wood-stud wall. The temperature was measured to be higher along the facade of the building compared with temperatures measured at the vicinity of the corner of the building.

The method outlined for determining temperatures in the ground underneath a building by using the method outlined by Danish Standards $[8,12]$ was shown to be in agreement with temperature measurements carried out on site. However, using the PC finite difference program HEAT2 for 2D and HEAT3 for 3D, calculations were shown to provide conservative results that would ensure a stable non-freezing ground underneath the strip foundation that was used as the base of a small residential building. Conservative results in the sense that for comparable results in time, between measured temperatures on site and calculated temperatures, the calculated temperatures were shown to be comparable with and just below the measured temperatures. Using the calculated temperatures for the design of the building, the solution on site was ensured to be stable with a non-freezing ground beneath the strip foundation. Ensuring stable non-freezing ground underneath a building is necessary for maintaining the stability of the structure and avoids settling cracks.

\section{Thermal Bridges in the Building Envelope}

Calculations of the temperature, shown as isotherm curves and the heat flow through the strip foundation at the base of a small residential building constructed with either a traditional wood-stud exterior wall with mineral fiber insulation or a double-brick exterior wall separated by mineral fiber insulation, showed almost identical temperatures at the inner overall wall surface towards the floor panel meeting the new building regulations. By using the EPS element it was demonstrated that a full and continuous cover of the heated part of a building can be established at the joint between the exterior wall and the ground floor slab. The stripfoundation element has been shown to be able to provide an energy-efficient solution for the strip foundation of small residential buildings constructed with both double-brick exterior walls and traditional wood-stud exterior walls. The strip foundation was found to be less energy-efficient for the building with a double-brick exterior wall due to the beam of concrete necessary to support the inner brick wall of the exterior wall. This beam was not necessary for the support of the traditional wood-stud exterior wall with mineral fiber insulation.

\section{CONCLUSION}

This study investigated the performance of a prefabricated lightweight EPS element used as the strip foundation and the base of two small residential buildings, in this case single-family houses constructed with either a traditional wood-stud exterior wall with mineral fiber insulation or a double-brick exterior wall separated by mineral fiber insulation. The EPS element was designed for a high energyefficient solution and it was shown to be even more efficient in practice than what is required in order to comply with the new tightened Danish Building Regulations [7]. Furthermore, it was demonstrated that outer insulation is needed to ensure stable non-freezing ground beneath the buildings, which is necessary for maintaining the stability of the structure and for preventing settling cracks during a cold winter. The designed EPS element was then used in a real-life situation, where the construction of two small residential buildings and normal weather conditions affected the working operation and the handling of the lightweight EPS element used as strip foundation and the base of either a traditional wood-stud exterior wall with mineral fiber insulation or a traditional double-brick exterior wall separated with mineral fiber insulation.

The EPS element was designed to perform as a strip foundation element used as the base of a small building. It was shown that the element could be built on stable ground and mounted on a capillary break layer of stamped gravel, only $0.25 \mathrm{~m}$ beneath the finished ground surface. Stable nonfreezing ground beneath the buildings was ensured by using insulation located at the outer plinth. The base of the house was cast in one working operation and completed within two working days. The element was handled on site by one man.

The method outlined for determining temperatures in the ground beneath a building combined with experience to ensure stable non-freezing ground beneath a building was shown to be in agreement with temperature measurements carried out on site. The method for calculating the temperatures under the strip foundation, outlined by Danish Standards $[8,12]$, was shown to bee in good agreement with the temperature measurements carried out on site.

In conclusion, this study has demonstrated that by using the EPS element, a full and continuous cover of the heated 
part of a building can be established at the joint between the exterior wall and the ground floor slab. The strip-foundation element was shown to be able to provide a high energyefficient solution for the strip foundation of small buildings not exceeding two stories constructed with double-brick exterior walls separated with mineral fiber insulation and traditional wood-stud exterior walls with mineral fiber insulation.

\section{ACKNOWLEDGEMENT}

Sundolitt A/S, Denmark, has supported this field study.

\section{REFERENCES}

[1] National Agency for Transport and Energy, "Handlingsplan for en fornyet energispareindsats" (Action plan for new energy savings) 2006. [Online]. Copenhagen: National Agency for Transport and Energy, Available from: http://www.ens.dk/graphics/Publikationer/Energipolitik/TRM_handlingsplan_web.pdf. [In Danish].

[2] United Nations, "Kyoto protocol to the United Nations framework convention on climate change", New York; United Nations, 1998. [Online] Available from: http://unfccc.int/resource/docs/convkp/kpeng.-pdf

[3] J. E. Olesen, S. Gyldenkærne, S. O. Petersen, M. H. Mikkelsen, B. H. Jacobsen, L. Vesterdal, A. M. K. Jørgensen, B. Tolstrup Christensen, J. Abildtrup. T. Heidmann, and G. Holton Rubæk, "Jordbrug og klimaændringer - samspil til vandmiljøplaner, (DJF rapport. Markbrug ; nr.109-2004), (Agriculture and climate change correlations to water environment), Tjele: Danmarks JordbrugsForskning, 2004. [Online]. Available from: http://www.vmp3.dk/Files/-Filer/Rap_fra_t_grupper/Jordbrug-og-Klimaraendringer13-09-2004.pdf, [In Danish].

[4] J. E. Olesen, "Water resources and climate change: Impacts on agriculture in Europe," In International workshop on climate change impacts on the water cycle, resources and quality", Book of abstracts, International workshop on climate change impacts on the water cycle, resources and quality, Brussels, September 25 and 26 , Brussels: European Commision 2006, pp. 37-41.
[5] National Agency for Enterprise and Construction, Bygningsreglement 1998, Danish Building Regulations for small buildings 1998, Copenhagen: National Agency for Enterprise and Construction, 1998. [with amendments] [Online] Available from: http://www.ebst.dk/br08.dk/BRS98/1/54/0, [In Danish]

[6] National Agency for Enterprise and Construction, "Bygningsreglement for småhuse 1998, Supplement no. 11", Danish building regulations for small buildings 1998, Copenhagen: National Agency for Enterprise and Construction, 1998. [with amendments], [Online] Available from: http://www.ebst.dk/file/4297/tillaeg 11_brs98.pdf, [In Danish].

[7] National Agency for Enterprise and Construction, "Bygningsreglement 2008", Danish Building Regulations 2008, Copenhagen: National Agency for Enterprise and Construction, 2008 [with amendments], [Online] Available from: http://www.ebst.dk/br08.dk/BR07/0/54/0, [In Danish].

[8] Danish Standards, Beregning af bygningers varmetab DS 418, 6th ed., Calculation of heat loss from buildings, Copenhagen 2002, [In Danish].

[9] European Committee for Standardization, CEN, "Thermal performance of buildings - Heat transfer via the ground - Calculation methods, European standard ISO/DIS 13370:2005", Brussels 2005.

[10] Lund Group for Computational Building Physics, Department of Building Physics, "HEAT2 - Heat transfer in two dimensions", Lund, [Online] Available: http://www.buildingphysics.com/indexfiler/heat2.htm

[11] Danish Standards, Beregning af Bygningers Varmetab DS 418, Addition 1, 6th ed. Calculation of heat loss from buildings, Copenhagen: 2005 [In Danish].

[12] Danish Standards, Bygningers Termiske Ydeevne - Konstruktion af Fundamenter Til-Forebyggelse af frostforskydning, DS/EN ISO 13793, version 1, Thermal performance of buildings - Thermal design of foundations to avoid frost heave, Copenhagen: 2001 [In Danish].

[13] J. Rose, "Konstruktioners frostsikkerhed", Frost resistance of constructions, Danish Technical University, BYG-DTU, Lyngby 2006 [In Danish].

(C) T. V. Rasmussen; Licensee Bentham Open.

This is an open access article licensed under the terms of the Creative Commons Attribution Non-Commercial License (http://creativecommons.org/licenses/by-nc/3.0/) which permits unrestricted, non-commercial use, distribution and reproduction in any medium, provided the work is properly cited. 